\title{
Natural hazard information and migration across cities: evidence from the anticipated Nankai Trough earthquake
}

\section{Michio Naoi ${ }^{1} \cdot$ Keiichi Sato ${ }^{2}$ Yozo Tanaka ${ }^{3} \cdot$ Hiroaki Matsuura ${ }^{4}$. Shingo Nagamatsu ${ }^{5}$}

Published online: 4 May 2020

(C) The Author(s) 2020

\begin{abstract}
This paper examines the effects of the 2012 revisions to the damage predictions of an anticipated Nankai Trough megathrust earthquake on subsequent intermunicipality migration in Japan's coastal areas. We find that an increase in predicted tsunami height-rather than anticipated seismic movements - after the 2012 revision is associated with a subsequent reduction in net migration. While the reducing effect of tsunami predictions on in-migration persisted throughout the study period, the effect on out-migration was only temporary. Moreover, workingage people are more likely to respond to tsunami risk and avoid moving to municipalities with a high tsunami risk after the revisions.
\end{abstract}

Keywords Hazard information $\cdot$ Damage predictions $\cdot$ Earthquake $\cdot$ Tsunami $\cdot$ Migration

\section{Introduction}

The 2011 Great East Japan Earthquake and subsequent tsunami evoke the terror unleashed by tsunamis and underscore the need to promote hazard maps and

\author{
Michio Naoi \\ naoi@econ.keio.ac.jp \\ Keiichi Sato \\ satok@isc.senshu-u.ac.jp \\ Yozo Tanaka \\ tanaka-y22ak@mlit.go.jp \\ Hiroaki Matsuura \\ hiroaki.matsuura@shoin-u.ac.jp \\ Shingo Nagamatsu \\ nagamatu@kansai-u.ac.jp
}

Extended author information available on the last page of the article 
evacuation drills to prepare for future calamities. More than $90 \%$ of the catastrophe's 15,899 deaths have been attributed to drowning during the tsunami. Due to growing concern over potential megathrust earthquakes after the 2011 catastrophe, the Japanese government revised the damage estimates for another potential megathrust earthquake - the Nankai Trough earthquake - in 2012, updating them from previous ones in 2001 and 2003.

The Nankai Trough earthquake is a type of megathrust earthquake that had been anticipated for decades by seismology researchers and policymakers in Japan (Ando 1975). The 2012 revisions to damage estimates include maximum possible seismic movements and their consequent tsunami height in each municipality, together with human and economic losses that may be triggered by the next Nankai Trough earthquake. According to this estimate, the total death toll in the worst-case scenario would be as much as 323,000 , with $71 \%$ due to a tsunami. Economic losses are estimated at approximately 170 trillion Japanese yen (JPY) in assets and 45 trillion JPY in the degradation of production and services.

This paper investigates the effect of hazard information regarding anticipated major disasters on migration behavior. Specifically, we employed a difference-in-differences type strategy, comparing municipalities with changes in tsunami predictions from previous ones to those without any changes, to estimate the causal effects of the 2012 revisions on migration patterns in potentially affected areas.

There is a growing body of literature that investigates the relationship between migration and environmental catastrophes (Hunter 2005; Schultz and Elliott 2013; Hunter et al. 2015). Most previous studies focus on "reactive" migration-i.e., migration responses after observed disaster events. For example, previous studies examine the impact of earthquakes ( $\mathrm{Xu}$ and Wang 2019), flooding (Boustan et al. 2012; Gray and Mueller 2012; Husby et al. 2014), and hurricanes (Myers et al. 2008; Loebach 2016; Deryugina 2017) on subsequent migration and population changes. A general finding in these studies is that disasters tend to increase net migration away from disaster-stricken areas, partly due to changing risk perception toward similar incidents in the future. However, reactive migration can also depend upon post-disaster investment in protective infrastructure (Boustan et al. 2012; Husby et al. 2014), disaster aid and other government transfers to affected areas (Deryugina 2017), and changing labor market conditions due to disaster damage and restoration (Glay and Mueller, 2012). Hence, the relationship between observed disaster events and subsequent migration is rather complex.

Although literature is relatively scarce, there are also several recent studies focusing on "anticipatory" migration-i.e., migration responses to anticipated disasters that are yet to occur. Existing works on this topic primarily center on environmental migration in the context of climate change (Millock 2015). Such works typically assume that the ex-ante climate-related risk can be represented by the past variability of local temperature (Dillon et al. 2011), precipitation (Dallmann and Millock 2017), or both (Bohra-Mishra et al. 2017).

Climate variability can influence risk perceptions of climate change and, thereby, migration patterns. However, as Bardsley and Hugo (2010) argue, past climate variability has other processes through which it affects migration patterns. For example, greater climate variability is often associated with past weather anomalies such as 
above-average rainfall and drought. These weather anomalies, particularly minor ones, usually do not come with sudden-onset disasters causing significant human and economic losses. Nonetheless, they can change long-term trends in resource conditions, such as agricultural productivity and water availability, potentially affecting migration patterns.

In contrast, revisions to hazard information alter risk perception toward potential catastrophes while not substantially affecting other factors that induce disaster-related migration. However, little is known about migration responses to the natural hazard information, although there are several empirical studies investigating house price responses (Brookshire et al. 1985; Nakanishi 2016; Singh 2019). To our knowledge, this paper is the first to present empirical evidence on anticipatory migration in the context of low-frequency but high-consequence natural hazards. Furthermore, since hazard information is an essential way to communicate potential risks to the public, how people react to such information has important policy implications regarding adaptation to environmental changes.

Our empirical results indicate that people have tended to avoid moving to municipalities with a high risk of tsunami since the 2012 revisions, implying that updated predictions could decrease the overall population exposure to a tsunami hazard. However, further analysis also reveals that migration responses to the updated hazard information can be heterogeneous among population subgroups. We find that migration responses are substantially larger among the working-age population than among the elderly population. These results suggest that updated predictions might worsen a community's vulnerability conditions whereby the elderly are left behind in high-risk areas.

Since the updated damage predictions for the Nankai Trough earthquake were released shortly after the 2011 earthquake, our empirical results could be driven by the 2011 event, rather than by the 2012 revisions to the hazard information. However, we think this is unlikely for several reasons. First, our empirical analysis solely focuses on areas potentially affected by the Nankai Trough earthquake, which are geographically separated from areas directly affected by the 2011 earthquake (see the "Anticipated Nankai Trough earthquake and damage predictions" section for detail). Second, our empirical analysis uses a set of measures for the 2011 earthquake damage that can effectively control for reactive migration in our dataset. Third, we even further restrict our sample to municipalities that did not observe any 2011 tsunami damage, which does not change our main findings.

The rest of the paper is organized as follows. The "Anticipated Nankai Trough earthquake and damage predictions" section summarizes background information about Nankai Trough earthquakes and the CDMC's damage predictions. The "Data and variables" section describes the dataset and variables used in the analysis. The "Empirical analysis" section explains our empirical model and provides empirical results. The "Conclusion" section concludes the paper.

\section{Anticipated Nankai Trough earthquake and damage predictions}

The Nankai Trough earthquake is a type of megathrust earthquake anticipated to occur along the Nankai Trough off the Pacific coast. Figure 1 illustrates the location of the 
Nankai Trough together with the epicenter of the 2011 earthquake and the resulting tsunami areas. It shows that areas potentially affected by the Nankai Trough earthquake are largely distant from the epicenter of the 2011 earthquake and the Fukushima Nuclear Power Plant. As a result, these potentially affected areas do not geographically overlap either with the 2011 tsunami areas or with areas directly affected by the nuclear accident.

The Nankai Trough is located at the boundary where the Philippine Sea Plate is subducting beneath the Eurasian Plate, forming an active subduction zone. As a result, the area has witnessed a number of megathrust earthquakes, even in the past. Historical records show that such earthquakes have occurred since as early as the seventh century, with a returning interval of approximately 100-200 years (Ishibashi 2004).

Historical records on the harm caused by these earthquakes indicate that the Nankai Trough is divided into three fault segments: the Nankai, Tonankai, and Tokai segments (Furumura et al. 2011; see also Fig. 1). The most recent megathrust earthquake in the area was the 1946 Showa Nankai earthquake, triggered by the rupture of the Nankai segment, which occurred shortly after the 1944 Showa Tonankai earthquake, triggered by the rupture of the Tonankai segment. The most recent megathrust earthquake at the Tokai segment dates back to the 1854 Ansei earthquake, meaning that the Tokai segment is very likely to precipitate a great earthquake in the near future. Furthermore, historical evidence indicates that the rupture of one segment is often followed by the rupture of other ones, resulting in a single gigantic event.

Given these facts, the Japanese government (the Headquarters for Earthquake Research Promotion) estimates a 70-80\% chance that such an incident will take place within the next 30 years. The government has also provided detailed damage predictions for such earthquakes, which typically include possible seismic movements and

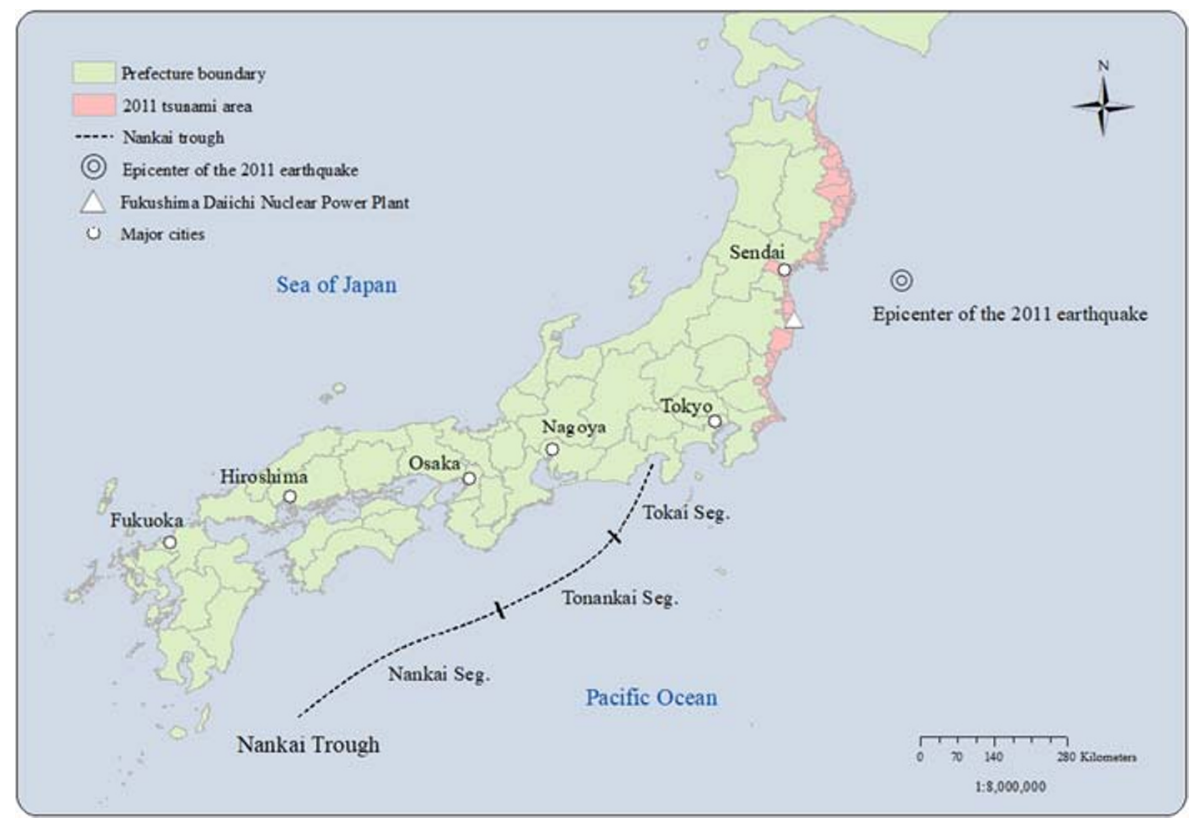

Fig. 1 Nankai Trough and the 2011 Great East Japan Earthquake 
resulting tsunami height, as well as economic and human losses under a variety of scenarios. Previous predictions are available for Tokai earthquakes, released in 2001, and for Nankai and Tonankai earthquakes, released in 2003.

More recently, these separate predictions were combined and revised in 2012 due to growing concern over potential megathrust earthquakes after the 2011 catastrophe. Since the 2011 tsunami engendered human and property damage that was far greater than previously anticipated, the 2012 report substantially upgraded the scale and spatial scope of a potential earthquake. While prior estimates assumed an earthquake of magnitude from 8.0 to 8.4 , the 2012 estimates assumed a magnitude of 9.1 , which is, based on up-to-date scientific evidence, thought to be the largest possible magnitude in the area. As a result, forecasted seismic movements and tsunami height were raised in almost all municipalities. In addition, changes in tsunami prediction from previous estimates differ substantially across municipalities, primarily due to data and methodological updates. While most municipalities saw substantial but modest increases in their predicted tsunami heights, a small number saw a drastic rise from the previous estimates. This renders a substantial inter-municipality variation in updated information regarding predicted tsunami height.

\section{Data and variables}

\section{Inter-municipality migration}

The data on migration comes from the Report on Internal Migration, compiled by the Statistics Bureau of Japan. The report provides information on in- and out-migration, as well as the total number of residents for all municipalities. The dataset is derived from the Basic Resident Registry (BRR) system. The BRR is a registry of residents maintained by local governments; resident registration is compulsory according to the Basic Resident Registration Act of 1967.

The in-migration rate is defined as the total number of in-migrants to municipality $i$ during year $t$, divided by the total population of municipality $i$ at the beginning of year $t$. The out-migration rate is defined in the same way. We also construct the net migration rate, which is simply defined as the in-migration rate minus the out-migration rate.

\section{Predicted seismic movements and tsunami height}

The CDMC's latest report estimates the maximum possible seismic movements and their resulting tsunami height for all municipalities, which were updated from the previous ones released in 2003 . We use a change in predicted tsunami height between the 2003 and 2012 CDMC reports as our main variable of interest.

The CDMC report also provides information on predicted seismic movements measured by the Japan Meteorological Agency's (JMA) seismic intensity scale. The JMA seismic intensity scale, which is gauged with a seismic intensity meter, provides a measure of the strength of seismic motion and is expressed in levels of seismic intensity from 0 (weakest) to 7 (strongest). Intensities of 5 and 6 are further divided into two levels, lower/upper 5 and lower/upper 6 . We regard earthquake ground motion with a JMA seismic intensity scale of upper 6 or greater as a megathrust earthquake. This is 
because a wide range of utility services (including gas, water, and electricity) may cease for homes and businesses over a wide range of areas in the event of an earthquake with this level of JMA seismic intensity. A dummy variable for differences in predicted seismic movements is 1 if a municipality's maximum possible seismic movement is upper 6 or greater in 2012, but lower 6 or less in the 2003 report. Otherwise, it is 0 .

\section{Control variables}

We also use a number of municipality-level control variables that can potentially influence in- and out-migration rates. As mentioned earlier, a major concern in our empirical analysis is that the 2011 earthquake possibly impacted observed migration patterns during our sample period. To control for damage from the 2011 earthquake and its influence on migration patterns, we include the following variables in our regression models: deaths and injuries per 10,000 residents from the 2011 earthquake and tsunami, percentage of residents living in the 2011 tsunami-affected areas, number of buildings damaged by the earthquake, whether municipalities are covered by the Disaster Relief Act, and the distance from the Fukushima Nuclear Power Plant. All of these variables interacted with a post-2011 dummy to capture the potential migratory impact of the 2011 earthquake - i.e., reactive migrations. Note, however, that municipalities used in our empirical analysis experienced relatively minor damage from the 2011 earthquake since they are largely distant from the 2011 earthquake areas (see the next section for details).

We also included the probability of a major earthquake in order to control for underlying risk. The data on earthquake probability is taken from the probabilistic seismic hazard map (PSHM) (National Research Institute for Earth Science and Disaster Resilience 2016). The PSHM shows the probability of an earthquake with a JMA seismic intensity of upper 6 or greater occurring within the next 30 years in a given area. The original data give the earthquake probabilities for every $250 \mathrm{~m} \times 250 \mathrm{~m}$ grid cells all over Japan. In the following analysis, the original data are spatially aggregated (i.e., taking a spatial average) at the municipality level.

In addition, a set of municipality characteristics is also included. These include age distribution (percent of the population aged 0-14 and 65+), population density, per capita income, the number of airports and railway stations, length (miles) of public roads, and the number of manufacturing establishments. A brief description and the data source of these control variables are given in Appendix Table 9.

\section{Estimation sample}

We compile the municipality-level longitudinal data for 2008-2015. Since the updated hazard information was released in 2012, the first half of our dataset represents the pretreatment period (2008-2011), and the rest represents the post-treatment period (20122015). Our original dataset covers all 1741 municipalities as of January 2015. However, since the predicted tsunami damages are highly concentrated along the coastal areas of southeast Japan, we restrict our sample in the following way.

Based on the Act on Special Measures for Promotion of Nankai Trough Earthquake Disaster Management of 2013, municipalities in 26 prefectures are designated to reinforce the evacuation plan in the event of a tsunami triggered by an earthquake. 
Coastal municipalities in these prefectures are most likely to be affected by seismic tremors and tsunamis produced by the next Nankai Trough megathrust earthquake. In comparison, neighboring inland municipalities are likely to be impacted by seismic tremors, but not by a high tsunami. Hence, neighboring municipalities can serve as an ideal control group for coastal municipalities.

In the following analysis, we restrict our sample to these coastal and neighboring municipalities. There are a number of municipal mergers during our sample period. The data for municipalities involved in the mergers are rearranged so that pre- and postmerge data are comparable. For example, if municipalities A and B are consolidated into municipality $\mathrm{C}$, then we aggregate the data for the municipalities in the pre-merger periods. Our sample restriction leads to 430 unique municipalities, of which 251 are coastal and 179 are inland. Consequently, the dataset used for our empirical analysis includes 3440 observations (i.e., 430 municipalities for 8 years, 2008-2015).

Figure 2 shows their locations. Compared to Fig. 1, the municipalities in our empirical analysis, in most cases, do not geographically overlap with the 2011 tsunami areas or those directly affected by the Fukushima nuclear accident. Our sample restriction, therefore, minimizes the migration responses to the 2011 earthquake itself and allows us to highlight the role of updated hazard information on migration behavior.

\section{Descriptive statistics}

Tables 1 and 2 present the summary statistics and distribution of municipalities in terms of the changes in predicted tsunami height between 2003 and 2012. Table 2 shows that

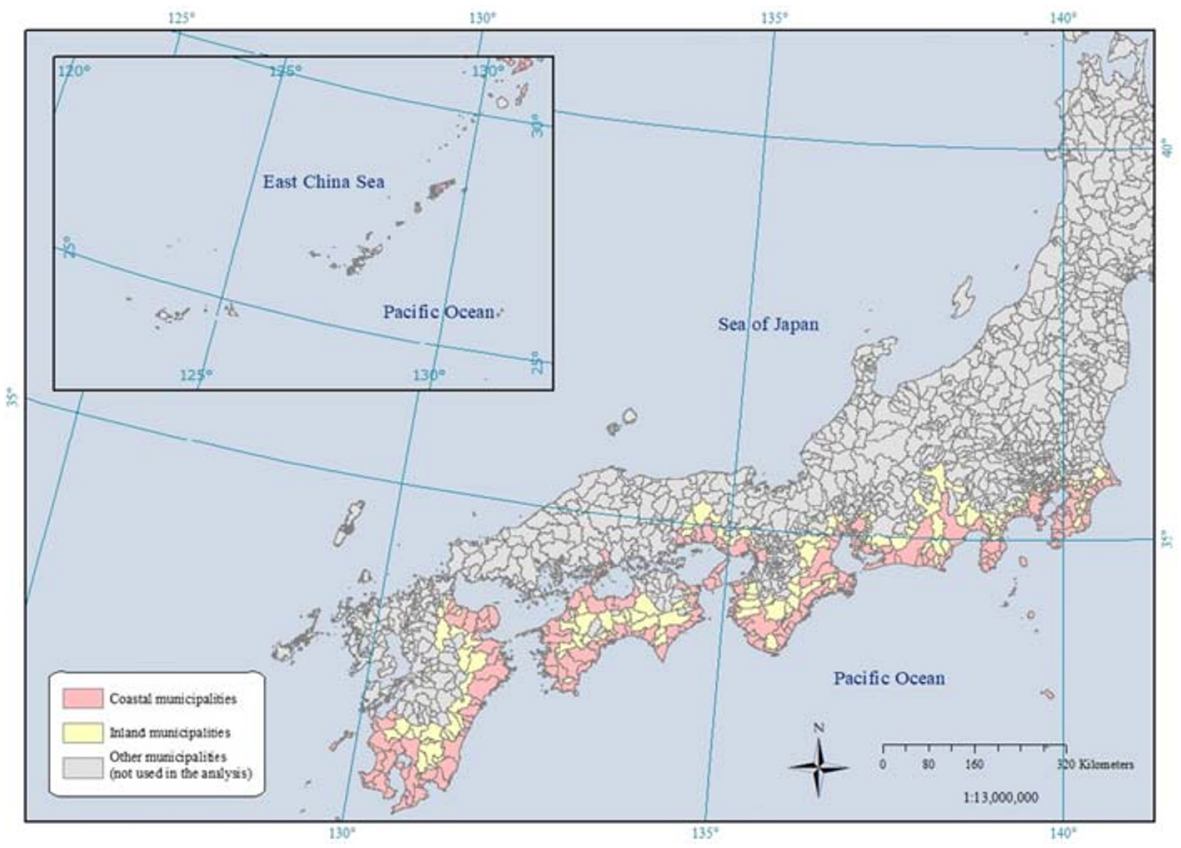

Fig. 2 Locations of municipalities in the estimation sample 
Table 1 Summary statistics

\begin{tabular}{|c|c|c|c|c|}
\hline Variables & Mean & $(\mathrm{SD})$ & Min. & Max. \\
\hline Net migration rate (annual, \%) & -0.227 & $(0.684)$ & -8.092 & 5.096 \\
\hline In-migration rate (annual, \%) & 3.593 & $(1.753)$ & 1.240 & 21.019 \\
\hline Out-migration rate (annual, \%) & 3.820 & $(1.511)$ & 1.800 & 20.833 \\
\hline Changes in predicted tsunami height $(\mathrm{m})$ & 2.984 & $(4.395)$ & -1.000 & 25.000 \\
\hline $\begin{array}{l}\text { Predicted seismic intensity ( } 1 \text { if upper } 6 \text { or greater in the } 2012 \text { report } \\
\text { and lower } 6 \text { or less in the } 2003 \text { report) }\end{array}$ & 0.307 & $(0.461)$ & 0.000 & 1.000 \\
\hline Number of deaths from the 2011 earthquake (per 10,000 residents) ${ }^{\dagger}$ & 0.010 & $(0.112)$ & 0.000 & 2.040 \\
\hline Number of injuries from the 2011 earthquake (per 10,000 residents) ${ }^{\dagger}$ & 0.080 & $(0.450)$ & 0.000 & 5.802 \\
\hline$\%$ residents living in the 2011 tsunami-affected areas ${ }^{\dagger}$ & 0.320 & $(2.787)$ & 0.000 & 42.456 \\
\hline $\begin{array}{l}\text { Number of buildings damaged by the } 2011 \text { earthquake (per 10,000 } \\
\text { residents) })^{\dagger}\end{array}$ & 15.14 & $(88.73)$ & 0.000 & 1176.7 \\
\hline Municipalities covered by the Disaster Relief Act ( 1 if yes) $)^{\dagger}$ & 0.060 & $(0.238)$ & 0.000 & 1.000 \\
\hline Distance from the Fukushima Daiichi Nuclear Power Plant $(\mathrm{km})^{\dagger}$ & 605.7 & $(320.4)$ & 167.4 & 1619.1 \\
\hline $\begin{array}{l}\text { Probability of an earthquake with JMA seismic intensity of upper } 6 \text { or } \\
\text { greater }\end{array}$ & 0.088 & $(0.110)$ & 0.000 & 0.614 \\
\hline$\%$ aged $0-14$ & 12.38 & $(2.41)$ & 3.50 & 22.23 \\
\hline$\%$ aged $65+$ & 28.38 & $(7.45)$ & 10.74 & 56.30 \\
\hline Population density (per sq. km) & 1459.9 & $(2922.4)$ & 2.157 & $18,062.0$ \\
\hline Log of per capita income (10,000 JPY) & 4.732 & $(0.355)$ & 3.790 & 6.628 \\
\hline Number of major airports (per sq. km) & 0.001 & $(0.010)$ & 0.000 & 0.161 \\
\hline Number of railway stations (per sq. km) & 0.125 & $(0.426)$ & 0.000 & 5.886 \\
\hline Miles of public roads (per sq. km) & 6.953 & $(5.505)$ & 0.491 & 26.175 \\
\hline Number of manufacturing establishments (per sq. km) & 2.491 & $(6.085)$ & -0.013 & 96.938 \\
\hline Sample size & 3440 & & & \\
\hline
\end{tabular}

$\dagger$ Summary statistics for damage from the 2011 earthquake are for years between 2011 and $2015(N=2150)$

about half of all municipalities in our sample $(N=195)$ see no changes in their tsunami predictions. Most of these are inland municipalities that witness no tsunami damage

Table 2 Changes in predicted tsunami height

\begin{tabular}{llllll}
\hline $\begin{array}{l}\Delta \text { predicted tsunami } \\
\text { height }\end{array}$ & $\begin{array}{l}\text { Number of } \\
\text { municipalities }\end{array}$ & $(\%)$ & $\begin{array}{l}\text { predicted tsunami } \\
\text { height }\end{array}$ & $\begin{array}{l}\text { Number } \\
\text { of municipalities }\end{array}$ & $(\%)$ \\
\hline $0 \mathrm{~m}^{\dagger}$ & 195 & $(45.3)$ & $7 \mathrm{~m}$ & 14 & $(3.3)$ \\
$1 \mathrm{~m}$ & 46 & $(10.7)$ & $8 \mathrm{~m}$ & 12 & $(2.8)$ \\
$2 \mathrm{~m}$ & 32 & $(7.4)$ & $9 \mathrm{~m}$ & 11 & $(2.6)$ \\
$3 \mathrm{~m}$ & 23 & $(5.3)$ & $10 \mathrm{~m}$ & 11 & $(2.6)$ \\
$4 \mathrm{~m}$ & 28 & $(6.5)$ & $11-14 \mathrm{~m}$ & 16 & $(3.7)$ \\
$5 \mathrm{~m}$ & 14 & $(3.3)$ & $15 \mathrm{~m}+$ & 11 & $(2.6)$ \\
$6 \mathrm{~m}$ & 17 & $(4.0)$ & Total & 430 & $(100.0)$ \\
\hline
\end{tabular}

$\dagger 0 \mathrm{~m}$ includes one municipality, with lower prediction in 2012 than in 2003 
predictions in both the 2003 and 2012 reports. In coastal municipalities, changes in predicted tsunami height vary substantially. While a small number of coastal municipalities $(N=17)$ experience no changes in tsunami predictions, shifts in tsunami height are as high as $25 \mathrm{~m}$ in some municipalities. There is only one inland municipality that has a non-zero predicted tsunami height. We choose to exclude this municipality from our sample but this does not change our empirical results.

Figure 3 compares the net migration rates between coastal and neighboring inland municipalities over our sample period. Levels and trends in net migration are similar between the two groups prior to the release of revised hazard information in 2012 (dashed line). After 2012, however, the net migration rate becomes substantially smaller in coastal municipalities than in their inland counterparts.

We also estimate the regression model with interaction terms between a full set of year dummies and treatment (i.e., coastal municipality) indicators to see whether trends in migration rates are the same between coastal and inland municipalities. Controlling for a set of municipality-level characteristics and prefecture and year fixed effects, we cannot find any strong evidence of differential pre-treatment migration trends between coastal and neighboring inland municipalities.

\section{Empirical analysis}

\section{Empirical model}

Our main specification is as follows:

$$
y_{p m t}=\alpha+\beta_{0} \Delta s_{m}+\beta_{1} \Delta s_{m} \times d_{t}+x_{p m t}^{\prime} \gamma+\delta_{p}+\phi_{t}+\varepsilon_{p m t},
$$

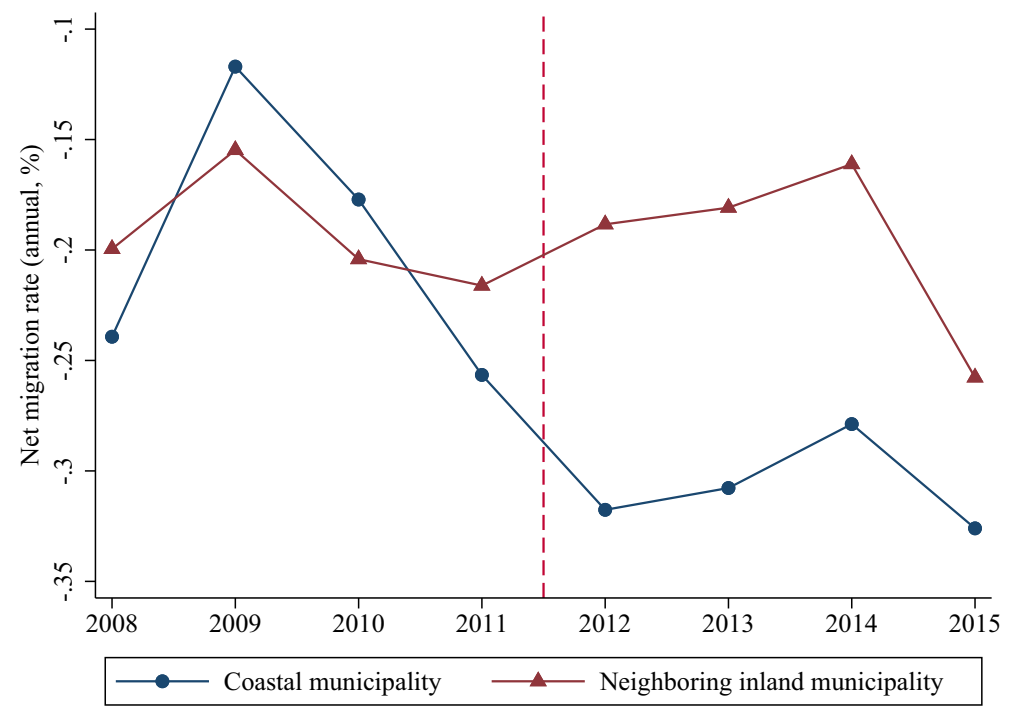

Fig. 3 Net migration rates in coastal and inland municipalities 
where $y_{p m t}$ is our dependent variable (i.e., net migration, in-migration, or out-migration rate) in municipality $m$ in prefecture $p$ in year $t . d_{t}$ is a dummy variable for the period after the release of the 2012 report. $\Delta s_{m}$ represents the differences in predicted seismic movements and their resulting tsunami height between the CDMC's reports from 2003 and 2012. The interaction term, $\Delta s_{m} \times d_{t}$, captures the effect of revised earthquake and tsunami hazard information released in 2012 on migration rates. $x_{p m t}$ contains a set of municipality-level characteristics that could potentially affect migration. $\delta_{p}$ and $\phi_{t}$ are prefecture and year fixed effects, respectively, and $\varepsilon_{p m t}$ signifies random errors.

We expect that $\beta_{0}$ equals 0 because information on $\Delta s_{m}$ is not available to people before the revisions in 2012. On the other hand, if people respond to the revised earthquake and tsunami hazard information after the release of the CDMC's report, $\beta_{1}$ is expected to be negative for the net migration/in-migration rates and positive for the out-migration rate.

The key assumption for Eq. (1) is that the treatment should be independent of the idiosyncratic shocks, conditional on observed covariates $(x)$ and a set of fixed effects $\left(\delta_{p}\right.$ and $\left.\phi_{t}\right)$. This assumption may not be plausible if there are unobserved heterogeneity at the municipality level and/or location-specific time trends. To control for potential unobserved heterogeneity at the municipality level and location-specific time trends, we add municipality fixed effects and prefecture×year fixed effects to Eq. (1). Our preferred specification is as follows:

$$
y_{p m t}=\alpha_{m}+\beta_{1} \Delta s_{m} \times d_{t}+x_{p m t}^{\prime} \gamma+\phi_{p t}+\varepsilon_{p m t},
$$

where $\alpha_{m}$ represents municipality fixed effects and $\phi_{p t}$ denotes prefecture $\times$ year fixed effects. $\Delta s_{m}$ is dropped from the specification due to the municipality fixed effects. Again, our coefficient of interest is $\beta_{1}$, which indicates people's response to the revised earthquake and tsunami hazard information.

We also consider a number of alternative specifications to Eq. (2). First, we test the nonlinear effect of tsunami hazard information by introducing a set of dummy variables for changes in predicted tsunami height. Second, we test the time-varying, post-treatment effects by replacing $d_{t}$ with a set of year dummies for the post-treatment period. Third, we check whether responses differ between the elderly and working-age populations by using age-specific migration rates as our dependent variable.

\section{Main results}

Table 3 presents our main empirical results. All estimations include municipality-level controls (discussed in the "Control variables" section), but the coefficient estimates of these control variables are not reported in the table. All standard errors are clustered at the municipality level.

Our regression results for the net migration rate are presented in columns [1] and [2], which correspond to Eqs. (1) and (2), respectively. These results indicate that, regardless of the model specification, an increase in predicted tsunami height significantly reduces net migration after the release of the 2012 CDMC's report. Estimated coefficients show that an additional 1-m increase in predicted tsunami height after the revision leads to a reduction of net migration rate by 0.017 and 0.026 percentage points, 
Table 3 Migration responses to revised hazard information

\begin{tabular}{|c|c|c|c|c|c|c|}
\hline \multirow[t]{3}{*}{ Dependent variables } & {$[1]$} & {$[2]$} & {$[3]$} & {$[4]$} & {$[5]$} & {$[6]$} \\
\hline & \multicolumn{2}{|c|}{ Net migration rate $(\%)$} & \multicolumn{2}{|c|}{ In-migration rate $(\%)$} & \multicolumn{2}{|c|}{ Out-migration rate $(\%)$} \\
\hline & $\begin{array}{l}\text { Coef. } \\
\text { (S.E.) }\end{array}$ & $\begin{array}{l}\text { Coef. } \\
\text { (S.E.) }\end{array}$ & $\begin{array}{l}\text { Coef. } \\
\text { (S.E.) }\end{array}$ & $\begin{array}{l}\text { Coef. } \\
\text { (S.E.) }\end{array}$ & $\begin{array}{l}\text { Coef. } \\
\text { (S.E.) }\end{array}$ & $\begin{array}{l}\text { Coef. } \\
\text { (S.E.) }\end{array}$ \\
\hline $\begin{array}{l}\text { Changes in predicted } \\
\text { tsunami height }\end{array}$ & $\begin{array}{r}-0.0060 \\
(0.0039)\end{array}$ & & $\begin{array}{l}0.0183 \\
(0.0156)\end{array}$ & & \multicolumn{2}{|l|}{$\begin{array}{c}0.0243 \\
(0.0155)\end{array}$} \\
\hline $\begin{array}{l}\text { Changes in predicted } \\
\text { tsunami height } \times \text { after } \\
\text { the } 2012 \text { revision }\end{array}$ & $\begin{array}{c}-0.0169 * * * \\
(0.0048)\end{array}$ & $\begin{array}{c}-0.0258 * * * \\
(0.0052)\end{array}$ & $\begin{array}{c}-0.0117 * * \\
(0.0053)\end{array}$ & $\begin{array}{c}-0.0133 * * * \\
(0.0040)\end{array}$ & $\begin{array}{l}0.0052 \\
(0.0036)\end{array}$ & $\begin{array}{l}0.0126 * * * \\
(0.0033)\end{array}$ \\
\hline $\begin{array}{l}\text { Predicted seismic } \\
\text { intensity ( } 1 \text { if upper } 6 \\
\text { or greater in } 2012 \text { but } \\
\text { lower } 6 \text { or less in } \\
2003 \text { ) }\end{array}$ & $\begin{array}{l}0.0433 \\
(0.0485)\end{array}$ & & $\begin{array}{l}0.2097 * \\
(0.1104)\end{array}$ & & $\begin{array}{c}0.1664 \\
(0.1022)\end{array}$ & \\
\hline $\begin{array}{l}\text { Predicted seismic } \\
\text { intensity } \times \text { after the } \\
2012 \text { revision }\end{array}$ & $\begin{array}{r}-0.0048 \\
(0.0371)\end{array}$ & $\begin{array}{r}-0.0341 \\
(0.0507)\end{array}$ & $\begin{array}{r}-0.0581 \\
(0.0462)\end{array}$ & $\begin{array}{r}-0.0390 \\
(0.0364)\end{array}$ & $\begin{array}{r}-0.0534 \\
(0.0428)\end{array}$ & $\begin{array}{r}-0.0049 \\
(0.0373)\end{array}$ \\
\hline \multicolumn{7}{|l|}{ Fixed effects } \\
\hline Prefecture & Yes & No & Yes & No & Yes & No \\
\hline Municipality & No & Yes & No & Yes & No & Yes \\
\hline Year & Yes & No & Yes & No & Yes & No \\
\hline Prefecture $\times$ year & No & Yes & No & Yes & No & Yes \\
\hline Adjusted $R^{2}$ & 0.4249 & 0.5777 & 0.6827 & 0.9594 & 0.5716 & 0.9501 \\
\hline Sample size & 3440 & 3440 & 3440 & 3440 & 3440 & 3440 \\
\hline
\end{tabular}

$* * *, * *$, and $*$ indicate the estimated coefficients are significant at the 1,5 , and $10 \%$ levels, respectively. Robust standard errors clustered by municipality are presented in the parentheses. The following control variables are included in all estimations, but results are omitted from the table: the number of deaths/injuries from the 2011 earthquake and tsunami (per 10,000 residents), \% of population living in the 2011 tsunamiaffected areas, number of buildings damaged by the 2011 earthquake, municipalities covered by the Disaster Relief Act, distance from the Fukushima Nuclear Power Plant, predicted probability of an earthquake with JMA seismic intensity of upper 6 or greater, $\%$ of population aged $0-14, \%$ of population aged $65+$, population density, income per capita, the number of airports and railway stations, miles of public roads, the number of manufacturing establishments

respectively. These numbers seem quite small, but given that the sample average of net migration is also small $(-0.227 \%)$, an additional $1-\mathrm{m}$ increase in tsunami height can lower the net migration rate by $7.5-11.4 \%$.

Results for in- and out-migration rates are presented in columns [3]-[6]. These results show that changes in predicted tsunami height after the revision can affect both in- and out-migrations. A higher tsunami prediction can decrease the inflow of people into a municipality, and also increase the outflow of local residents. Based on our preferred specifications with municipality fixed effects (columns [4] and [6]), the results indicate that these two effects are similar in terms of magnitude. The estimated coefficients suggest that the average coastal municipality experienced 93.1 fewer inmigrations and 88.3 more out-migrations due to the revised tsunami prediction, leading 
to 181.4 net population decrease. As for the revised seismic intensity predictions, we do not find any significant effects on all three migration measures.

\section{Nonlinearity of the impact of predicted tsunami height}

In order to examine the possible nonlinearity of the treatment effect, we categorize the municipalities into 13 groups based on changes in their tsunami height and create a set of dummy variables for these categories. Figure 4 illustrates the estimation results. This figure presents the marginal effects of the changes in predicted tsunami height at each point $\Delta s_{m}$, where vertical lines show $95 \%$ confidence intervals testing whether estimated marginal effects are different from the baseline without any changes (i.e., $\Delta s_{m}=$ $0)$.

Overall, as the changes in predicted tsunami height become higher, the net migration and in-migration rates tend to be lower, and the out-migration rate tends to be higher. However, in either case, statistically significant effects (as compared to baseline) can only be found in municipalities with extremely large changes in predicted tsunami height (more than $10 \mathrm{~m}$ ).

\section{Time-varying post-treatment effects}

Migration responses to the revised earthquake and tsunami hazard information can vary over time. For example, time-varying post-treatment effects can be observed if the relocation decision needs time to be realized due to transaction costs, or if people quickly become accustomed to the new information. In the former case, actual migration decisions are influenced by revised earthquake and tsunami hazard information with some time lags. In the latter case, migration responses can be observed only after the release of new information and dissipate over time.

In order to test the time-varying post-treatment effects, we replace $d_{t}$ in Eq. (2) with a set of year dummies for the post-treatment period. Table 4 summarizes the estimation results for this alternative specification, where treatment effects are estimated and presented separately for each year after 2012 .

The effects of predicted tsunami height on in-migration do not seem to dissipate over time, whereas the effects on out-migration can be found only in years between 2012 and 2014, and the coefficient sizes tend to be smaller in later years. In-migrants have already decided to relocate for reasons sometimes other than a tsunami hazard. They can easily substitute their new residence in risky coastal municipalities by the one in safer inland municipalities nearby. On the other hand, out-migration can be quite costly due to certain transaction costs. Those who out-migrate from municipalities with a high tsunami hazard just after the release of the 2012 information are most sensitive to anticipated tsunami risks. Later out-migrants are more likely to respond to anticipated tsunami hazards via intra-municipality migration because they know more about their municipality of residence.

We also find that an increase in seismic intensity predictions is significantly associated with a reduction in in-migration, but only for the year immediately following the dissemination of revised hazard information. However, the negative effect on in-migration fades quickly over time and is not large enough to cause long-term leveling effects in our main specification. 
(a) Net migration rate (\%)

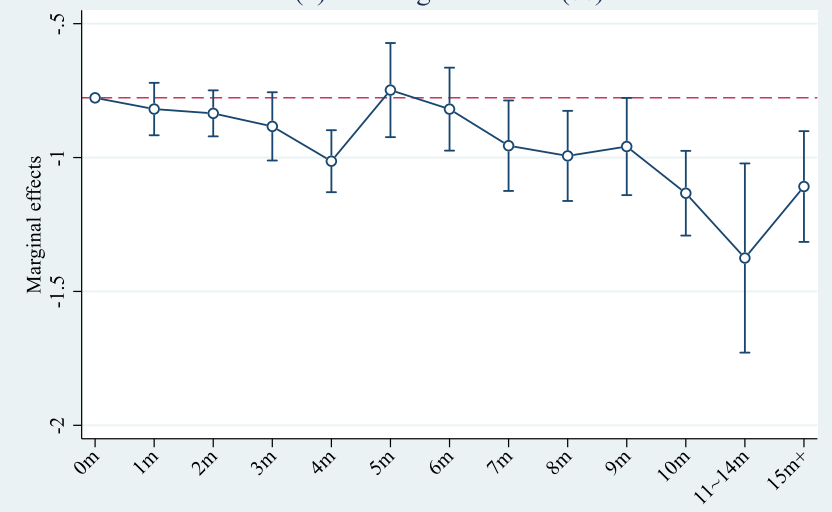

Changes in predicted tsunami height between 2003 and 2012

(b) In-migration rate $(\%)$

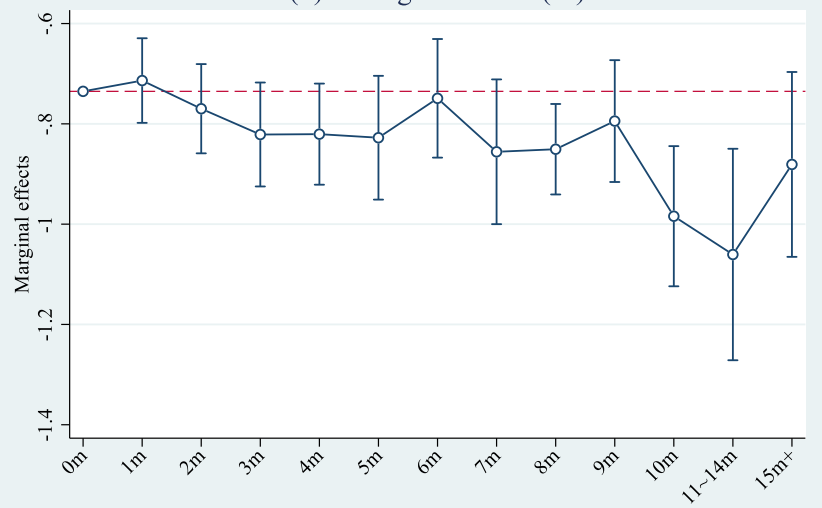

Changes in predicted tsunami height between 2003 and 2012

(c) Out-migration rate (\%)

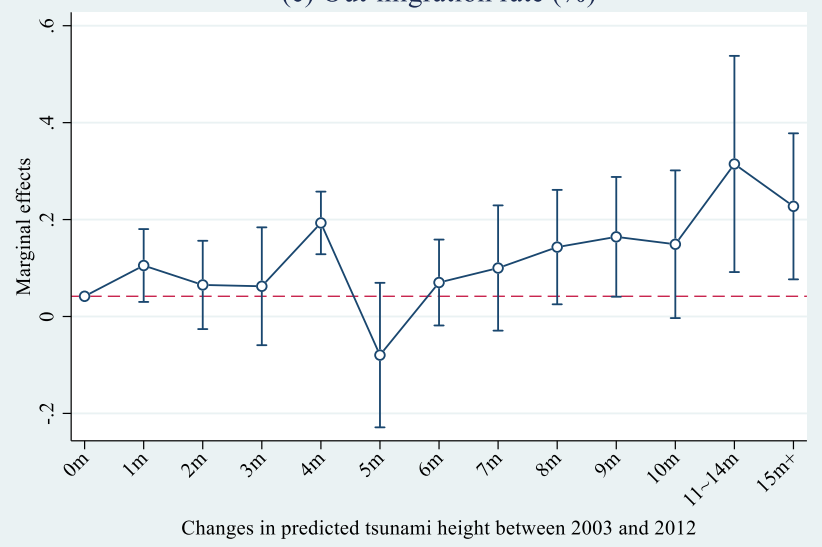

Fig. 4 Nonlinear effect of changes in predicted tsunami height 
Table 4 Time-varying treatment effects

\begin{tabular}{llll}
\hline Dependent variables & Net migration rate (\%) & In-migration rate (\%) & Out-migration rate (\%) \\
& Coef. & Coef. & Coef. \\
& (S.E.) & (S.E.) & (S.E.) \\
\hline
\end{tabular}

Changes in predicted tsunami height

$\begin{array}{cc}\times \text { Year }=2012 & -0.0275 * * * \\ & (0.0089) \\ \times \text { Year }=2013 & -0.0277 * * * \\ & (0.0073) \\ \times \text { Year }=2014 & -0.0235 * * * \\ \times \text { Year }=2015 & (0.0057) \\ & -0.0244 * * * \\ & (0.0057)\end{array}$

$-0.0122 * *$
$(0.0061)$
$-0.0148 * *$
$(0.0059)$
-0.0100
$(0.0065)$
$-0.0165 * * *$
$(0.0061)$

$0.0153 * * *$
$(0.0053)$
$0.0130 * *$
$(0.0053)$
$0.0135 * *$
$(0.0067)$
0.0078
$(0.0067)$

Predicted seismic intensity

$\begin{array}{cc}\times \text { Year }=2012 & -0.0331 \\ & (0.0671) \\ \times \text { Year }=2013 & -0.0881 \\ \times \text { Year }=2014 & (0.0730) \\ \times \text { Year }=2015 & -0.1290 * * \\ & (0.0655) \\ & 0.1133 \\ & (0.0941)\end{array}$

$-0.0953 * *$
$(0.0484)$
$-0.0891 *$
$(0.0505)$
-0.0399
$(0.0527)$
0.0703
$(0.0513)$

Fixed effects

$\begin{array}{lc}\text { Municipality } & \text { Yes } \\ \text { Prefecture } \times \text { year } & \text { Yes } \\ \text { Adjusted } R^{2} & 0.5783 \\ \text { Sample size } & 3440\end{array}$

$$
\begin{array}{cc}
\text { Yes } & \text { Yes } \\
\text { Yes } & \text { Yes } \\
0.9595 & 0.950 \\
3440 & 3440
\end{array}
$$$$
\text { Yes }
$$

3440

$* * *, * *$, and $*$ indicate the estimated coefficients are significant at the 1, 5, and $10 \%$ levels, respectively. Robust standard errors clustered by municipality are presented in the parentheses. The following control variables are included in all estimations, but results are omitted from the table: the number of deaths/injuries from the 2011 earthquake and tsunami (per 10,000 residents), \% of population living in the 2011 tsunamiaffected areas, number of buildings damaged by the 2011 earthquake, municipalities covered by the Disaster Relief Act, distance from the Fukushima Nuclear Power Plant, predicted probability of an earthquake with JMA seismic intensity of upper 6 or greater, $\%$ of population aged $0-14, \%$ of population aged $65+$, population density, income per capita, the number of airports and railway stations, miles of public roads, the number of manufacturing establishments

Furthermore, we could not find any effect of revised seismic intensity predictions on net migration or out-migration patterns.

\section{Heterogeneous effects across different age groups}

In this section, we provide additional empirical results on heterogeneous effects among different age groups. We compare the migration response between the working-age and 
elderly populations. To do this, we calculate the migration rate for the working-age population separately from the elderly population and run the same regression as Eq. (2). Table 5 displays the regression results. We find that migration responses are substantially larger among the working-age population compared to the elderly population.

\section{Tsunami prediction in levels and differences}

We test an alternative specification that additionally includes the 2012 tsunami prediction levels in our benchmark model to test whether people respond to 2012 tsunami prediction levels or their changes from previous estimates. The results presented in Table 6 indicate that changes and levels of tsunami predictions show contrasting effects on in- and out-migration rates. On the one hand, the changes in predicted tsunami height have a significant effect on out-migration but not on in-migration. On the other hand, tsunami prediction levels tend to have larger, though not statistically significant at the conventional level, effect on in-migration than on out-migration. These findings suggest that changes in tsunami predictions are important, particularly for existing local residents (i.e., out-migration behavior) since they are already informed about previous predictions. In comparison, incoming residents put relatively larger weight on the 2012

Table 5 Migration responses of working-age and elderly populations

\begin{tabular}{|c|c|c|c|c|c|c|}
\hline \multirow[t]{2}{*}{ Dependent variables } & \multicolumn{2}{|c|}{ Net migration rate $(\%)$} & \multicolumn{2}{|c|}{ In-migration rate $(\%)$} & \multicolumn{2}{|c|}{ Out-migration rate $(\%)$} \\
\hline & $\begin{array}{l}\text { Age 15-64 } \\
\text { Coef. } \\
\text { (S.E.) }\end{array}$ & $\begin{array}{l}\text { Age } 65+ \\
\text { Coef. } \\
\text { (S.E.) }\end{array}$ & $\begin{array}{l}\text { Age 15-64 } \\
\text { Coef. } \\
\text { (S.E.) }\end{array}$ & $\begin{array}{l}\text { Age } 65+ \\
\text { Coef. } \\
\text { (S.E.) }\end{array}$ & $\begin{array}{l}\text { Age 15-64 } \\
\text { Coef. } \\
\text { (S.E.) }\end{array}$ & $\begin{array}{l}\text { Age } 65+ \\
\text { Coef. } \\
\text { (S.E.) }\end{array}$ \\
\hline $\begin{array}{l}\text { Changes in predicted } \\
\text { tsunami height } \times \\
\text { after the } 2012 \\
\text { revision }\end{array}$ & $\begin{array}{c}-0.0201 * * * \\
(0.0064)\end{array}$ & $\begin{array}{r}-0.0056 \\
(0.0044)\end{array}$ & $\begin{array}{c}-0.0117 * * \\
(0.0052)\end{array}$ & $\begin{array}{c}0.0003 \\
(0.0025)\end{array}$ & $\begin{array}{c}0.0084 \\
(0.0054)\end{array}$ & $\begin{array}{r}0.0060 \\
(0.0037)\end{array}$ \\
\hline $\begin{array}{l}\text { Predicted seismic } \\
\text { intensity } \times \text { after } \\
\text { the } 2012 \text { revision }\end{array}$ & $\begin{array}{r}-0.0026 \\
(0.0764)\end{array}$ & $\begin{array}{r}-0.0205 \\
(0.0386)\end{array}$ & $\begin{array}{c}0.0415 \\
(0.0857)\end{array}$ & $\begin{array}{c}0.0114 \\
(0.0310)\end{array}$ & $\begin{array}{c}0.0441 \\
(0.0462)\end{array}$ & $\begin{array}{c}0.0319 \\
(0.0249)\end{array}$ \\
\hline \multicolumn{7}{|l|}{ Fixed effects } \\
\hline Municipality & Yes & Yes & Yes & Yes & Yes & Yes \\
\hline Prefecture $\times$ year & Yes & Yes & Yes & Yes & Yes & Yes \\
\hline Adjusted $R^{2}$ & 0.6344 & 0.4290 & 0.9502 & 0.7923 & 0.9261 & 0.7259 \\
\hline Sample size & 3008 & 3008 & 3008 & 3008 & 3008 & 3008 \\
\hline
\end{tabular}

$* * *, * *$, and $*$ indicate the estimated coefficients are significant at the 1,5 , and $10 \%$ levels, respectively. Robust standard errors clustered by municipality are presented in the parentheses. The following control variables are included in all estimations, but results are omitted from the table: the number of deaths/injuries from the 2011 earthquake and tsunami (per 10,000 residents), \% of population living in the 2011 tsunamiaffected areas, number of buildings damaged by the 2011 earthquake, municipalities covered by the Disaster Relief Act, distance from the Fukushima Nuclear Power Plant, predicted probability of an earthquake with JMA seismic intensity of upper 6 or greater, $\%$ of population aged $0-14, \%$ of population aged $65+$, population density, income per capita, the number of airports and railway stations, miles of public roads, the number of manufacturing establishments 
Table 6 Migration responses to changes and levels of revised tsunami predictions

\begin{tabular}{|c|c|c|c|c|c|c|}
\hline \multirow[t]{3}{*}{ Dependent variables } & {$[1]$} & {$[2]$} & & {$[4]$} & & [6] \\
\hline & \multicolumn{2}{|c|}{ Net migration rate $(\%)$} & \multicolumn{2}{|c|}{ In-migration rate $(\%)$} & \multicolumn{2}{|c|}{ Out-migration rate (\%) } \\
\hline & $\begin{array}{l}\text { Coef. } \\
\text { (S.E.) }\end{array}$ & $\begin{array}{l}\text { Coef. } \\
\text { (S.E.) }\end{array}$ & $\begin{array}{l}\text { Coef. } \\
\text { (S.E.) }\end{array}$ & $\begin{array}{l}\text { Coef. } \\
\text { (S.E.) }\end{array}$ & $\begin{array}{l}\text { Coef. } \\
\text { (S.E.) }\end{array}$ & $\begin{array}{l}\text { Coef. } \\
\text { (S.E.) }\end{array}$ \\
\hline $\begin{array}{l}\text { Changes in predicted } \\
\text { tsunami height }\end{array}$ & $\begin{array}{r}-0.0111 \\
(0.0073)\end{array}$ & & $\begin{array}{c}0.0254 \\
(0.0224)\end{array}$ & & $\begin{array}{c}0.0365 \\
(0.0226)\end{array}$ & \\
\hline $\begin{array}{l}\text { Changes in predicted } \\
\text { tsunami height } \times \text { after } \\
\text { the } 2012 \text { revision }\end{array}$ & $\begin{array}{c}-0.0158 * \\
(0.0082)\end{array}$ & $\begin{array}{c}-0.0221 * * * \\
(0.0070)\end{array}$ & $\begin{array}{r}-0.0017 \\
(0.0077)\end{array}$ & $\begin{array}{r}-0.0075 \\
(0.0054)\end{array}$ & $\begin{array}{l}0.0141 * \\
(0.0074)\end{array}$ & $\begin{array}{l}0.0146 * * * \\
(0.0054)\end{array}$ \\
\hline $\begin{array}{l}\text { Levels in predicted } \\
\text { tsunami height in the } \\
2012 \text { report }\end{array}$ & $\begin{array}{c}0.0064 \\
(0.0082)\end{array}$ & & $\begin{array}{r}-0.0091 \\
(0.0172)\end{array}$ & & $\begin{array}{r}-0.0154 \\
(0.0176)\end{array}$ & \\
\hline $\begin{array}{l}\text { Levels in predicted } \\
\text { tsunami height in the } \\
2012 \text { report } \times \text { after the } \\
2012 \text { revision }\end{array}$ & $\begin{array}{r}-0.0014 \\
(0.0079)\end{array}$ & $\begin{array}{r}-0.0047 \\
(0.0075)\end{array}$ & $\begin{array}{r}-0.0122 \\
(0.0079)\end{array}$ & $\begin{array}{r}-0.0072 \\
(0.0057)\end{array}$ & -0.0108 & $\begin{array}{r}-0.0025 \\
(0.0052)\end{array}$ \\
\hline $\begin{array}{l}\text { Predicted seismic } \\
\text { intensity }\end{array}$ & $\begin{array}{c}0.0483 \\
(0.0481)\end{array}$ & & $\begin{array}{l}0.1995 * \\
(0.1112)\end{array}$ & & $\begin{array}{c}0.1512 \\
(0.1027)\end{array}$ & \\
\hline $\begin{array}{l}\text { Predicted seismic } \\
\text { intensity } \times \text { after the } \\
2012 \text { revision }\end{array}$ & $\begin{array}{r}-0.0057 \\
(0.0374)\end{array}$ & $\begin{array}{r}-0.0382 \\
(0.0505)\end{array}$ & $\begin{array}{r}-0.0618 \\
(0.0466)\end{array}$ & $\begin{array}{r}-0.0453 \\
(0.0352)\end{array}$ & $\begin{array}{r}-0.0562 \\
(0.0445)\end{array}$ & $\begin{array}{r}-0.0071 \\
(0.0379)\end{array}$ \\
\hline \multicolumn{7}{|l|}{ Fixed effects } \\
\hline Prefecture & Yes & No & Yes & No & Yes & No \\
\hline Municipality & No & Yes & No & Yes & No & Yes \\
\hline Year & Yes & No & Yes & No & Yes & No \\
\hline Prefecture $\times$ year & No & Yes & No & Yes & No & Yes \\
\hline Adjusted $R^{2}$ & 0.4248 & 0.5776 & 0.6828 & 0.9594 & 0.5721 & 0.9501 \\
\hline Sample size & 3440 & 3440 & 3440 & 3440 & 3440 & 3440 \\
\hline
\end{tabular}

$* * *, * *$, and $*$ indicate the estimated coefficients are significant at the 1,5 , and $10 \%$ levels, respectively. Robust standard errors clustered by municipality are presented in the parentheses. The following control variables are included in all estimations, but results are omitted from the table: the number of deaths/injuries from the 2011 earthquake and tsunami (per 10,000 residents), \% of population living in the 2011 tsunamiaffected areas, number of buildings damaged by the 2011 earthquake, municipalities covered by the Disaster Relief Act, distance from the Fukushima Nuclear Power Plant, predicted probability of an earthquake with JMA seismic intensity of upper 6 or greater, $\%$ of population aged $0-14, \%$ of population aged $65+$, population density, income per capita, the number of airports and railway stations, miles of public roads, the number of manufacturing establishments

tsunami prediction levels than on their changes, since they are not always familiar with the previous predictions.

\section{Robustness checks}

As mentioned earlier, the Great East Japan Earthquake and its subsequent tsunami in 2011 can influence migration patterns. As a result, migration patterns after the release of the 2012 CDMC's report are influenced not only by the anticipation of the Nankai 
Trough Earthquake (i.e., anticipatory migration) but also by the occurrence of the 2011 earthquake (i.e., reactive migration). Although our choice of estimation sample together with the inclusion of various controls for earthquake and tsunami damage can minimize the direct impact of the 2011 earthquake, one may still think that our results can be driven by the changes in people's perception of tsunami risk as a result of the Great East Japan Earthquake and the subsequent tsunami in 2011.

The powerful tsunami triggered by this catastrophe devastated Japan's northeastern coast. The detrimental impact of this tsunami might change migration patterns in such a way that people move away from coastal areas and choose inland areas instead. This can bias our benchmark estimates. The changes in migration patterns described above can increase out-migration from coastal areas, where mostly nonzero tsunami predictions are observed. In contrast, inland municipalities can attract more in-migration. Hence, regression analysis based on Equations (1) and (2) using both coastal and inland municipalities as a regression sample may yield a spurious correlation between tsunami predictions and migration rates. In order to determine whether this is the case, we run the regression models using only the sample of coastal municipalities. There is substantial variation in changes in predicted height within coastal municipalities. The results, presented in Table 7 , indicate that the net migration rate is still negatively associated with changes in tsunami height within coastal municipalities.

Furthermore, the results also indicate that an increase in seismic intensity predictions is significantly associated with an increase in out-migration from coastal municipalities. This is consistent with the findings of Matsuura and Sato (2018), who show that land prices do not respond to the risk of large earthquakes alone, but rather to a high probability of large earthquakes when such a risk is combined with the risk of a tsunami.

In our base estimation sample, municipalities exposed to the 2011 tsunami are exclusively located in two prefectures - Ibaraki and Chiba prefectures. To see whether tsunami exposure affects our benchmark results, we estimate the same model as in Table 3 but exclude all municipalities in these two prefectures from our sample. The results, presented in Table 8 , indicate that the estimated coefficients on changes in tsunami height are slightly smaller in an absolute sense than those presented in Table 3. Nonetheless, they are statistically significant, with signs unchanged from our benchmark results. Our empirical results presented in Tables 7 and 8 suggest that our main findings on the effect of tsunami predictions are not solely driven by the 2011 earthquake and tsunami.

Our final robustness check is concerned with the choice of control municipalities. As explained in the "Estimation sample" section, our identification strategy essentially compares migration patterns between coastal municipalities with $\Delta s>0$ (treatment group) and neighboring inland municipalities with $\Delta s=0$ (control group). The underlying assumption of this setup is that migration rates in coastal municipalities would be the same as those in inland municipalities in the absence of the 2012 revision to tsunami predictions (i.e., parallel trend assumption).

As shown in Fig. 3, pre-treatment trends in net migration are similar between coastal and neighboring inland municipalities, which gives some confidence to our choice of control group. In general, however, the parallel trend 
Table 7 Migration responses in coastal municipalities

\begin{tabular}{|c|c|c|c|c|c|c|}
\hline \multirow[t]{3}{*}{ Dependent variables } & {$[1]$} & {$[2]$} & {$[3]$} & {$[4]$} & {$[5]$} & {$[6]$} \\
\hline & \multicolumn{2}{|c|}{ Net migration rate $(\%)$} & \multicolumn{2}{|c|}{ In-migration rate $(\%)$} & \multicolumn{2}{|c|}{ Out-migration rate $(\%)$} \\
\hline & $\begin{array}{l}\text { Coef. } \\
\text { (S.E.) }\end{array}$ & $\begin{array}{l}\text { Coef. } \\
\text { (S.E.) }\end{array}$ & $\begin{array}{l}\text { Coef. } \\
\text { (S.E.) }\end{array}$ & $\begin{array}{l}\text { Coef. } \\
\text { (S.E.) }\end{array}$ & $\begin{array}{l}\text { Coef. } \\
\text { (S.E.) }\end{array}$ & $\begin{array}{l}\text { Coef. } \\
\text { (S.E.) }\end{array}$ \\
\hline $\begin{array}{l}\text { Changes in predicted } \\
\text { tsunami height }\end{array}$ & $\begin{array}{c}-0.0098 * \\
(0.0054)\end{array}$ & & $\begin{array}{c}0.0200 \\
(0.0275)\end{array}$ & & $\begin{array}{c}0.0298 \\
(0.0276)\end{array}$ & \\
\hline $\begin{array}{l}\text { Changes in predicted } \\
\text { tsunami height } \times \text { after } \\
\text { the } 2012 \text { revision }\end{array}$ & $\begin{array}{c}-0.0139 * * * \\
(0.0053)\end{array}$ & $\begin{array}{c}-0.0192 * * * \\
(0.0065)\end{array}$ & $\begin{array}{r}-0.0024 \\
(0.0065)\end{array}$ & $\begin{array}{c}-0.0093 * \\
(0.0048)\end{array}$ & $\begin{array}{l}0.0116 * * \\
(0.0053)\end{array}$ & $\begin{array}{l}0.0099 * * \\
(0.0038)\end{array}$ \\
\hline $\begin{array}{l}\text { Predicted seismic } \\
\text { intensity ( } 1 \text { if upper } 6 \\
\text { or greater in } 2012 \text { but } \\
\text { lower } 6 \text { or less in } \\
\text { 2003) }\end{array}$ & $\begin{array}{c}0.0875 \\
(0.0622)\end{array}$ & & $\begin{array}{c}0.1363 \\
(0.1775)\end{array}$ & & $\begin{array}{c}0.0489 \\
(0.1627)\end{array}$ & \\
\hline $\begin{array}{l}\text { Predicted seismic } \\
\text { intensity } \times \text { after the } \\
2012 \text { revision }\end{array}$ & $\begin{array}{r}-0.0196 \\
(0.0390)\end{array}$ & $\begin{array}{c}-0.0988 * \\
(0.0529)\end{array}$ & $\begin{array}{r}-0.0321 \\
(0.0499)\end{array}$ & $\begin{array}{r}-0.0150 \\
(0.0460)\end{array}$ & $\begin{array}{r}-0.0125 \\
(0.0481)\end{array}$ & $\begin{array}{l}0.0838 * * \\
(0.0375)\end{array}$ \\
\hline \multicolumn{7}{|l|}{ Fixed effects } \\
\hline Prefecture & Yes & No & Yes & No & Yes & No \\
\hline Municipality & No & Yes & No & Yes & No & Yes \\
\hline Year & Yes & No & Yes & No & Yes & No \\
\hline Prefecture $\times$ year & No & Yes & No & Yes & No & Yes \\
\hline Adjusted $R^{2}$ & 0.3567 & 0.5268 & 0.6472 & 0.9625 & 0.5550 & 0.9557 \\
\hline Sample size & 2008 & 2008 & 2008 & 2008 & 2008 & 2008 \\
\hline
\end{tabular}

$* * *, * *$, and $*$ indicate the estimated coefficients are significant at the 1,5 , and $10 \%$ levels, respectively. Robust standard errors clustered by municipality are presented in the parentheses. The following control variables are included in all estimations, but results are omitted from the table: the number of deaths/injuries from the 2011 earthquake and tsunami (per 10,000 residents), \% of population living in the 2011 tsunamiaffected areas, number of buildings damaged by the 2011 earthquake, municipalities covered by the Disaster Relief Act, distance from the Fukushima Nuclear Power Plant, predicted probability of an earthquake with JMA seismic intensity of upper 6 or greater, $\%$ of population aged $0-14, \%$ of population aged $65+$, population density, income per capita, the number of airports and railway stations, miles of public roads, the number of manufacturing establishments

assumption cannot be directly tested, and the violation of the assumption may cause some bias. As an alternative to our benchmark model, we use the synthetic control (SC) method, originally developed by Abadie et al. (2010), to check the robustness of our main results.

Intuitively, the SC method constructs a synthetic unit by weighting municipalities in the control group in such a way that the pre-treatment outcomes and relevant covariates of the synthetic unit are close to those of the treated municipality. The synthetic unit can serve as the counterfactual to the treated municipality. In the posttreatment period, treatment effects can be measured by the difference between outcomes of the treated municipality and the synthetic unit. A detailed estimation procedure is given in Appendix 2. 
Table 8 Using municipalities unaffected by the 2011 earthquake

\begin{tabular}{|c|c|c|c|c|c|c|}
\hline \multirow[t]{3}{*}{ Dependent variables } & {$[1]$} & {$[2]$} & {$[3]$} & [4] & & {$[6]$} \\
\hline & \multicolumn{2}{|c|}{ Net migration rate $(\%)$} & \multicolumn{2}{|c|}{ In-migration rate $(\%)$} & \multicolumn{2}{|c|}{ Out-migration rate $(\%)$} \\
\hline & $\begin{array}{l}\text { Coef. } \\
\text { (S.E.) }\end{array}$ & $\begin{array}{l}\text { Coef. } \\
\text { (S.E.) }\end{array}$ & $\begin{array}{l}\text { Coef. } \\
\text { (S.E.) }\end{array}$ & $\begin{array}{l}\text { Coef. } \\
\text { (S.E.) }\end{array}$ & $\begin{array}{l}\text { Coef. } \\
\text { (S.E.) }\end{array}$ & $\begin{array}{l}\text { Coef. } \\
\text { (S.E.) }\end{array}$ \\
\hline $\begin{array}{l}\text { Changes in predicted } \\
\text { tsunami height }\end{array}$ & $\begin{array}{c}-0.0069 * \\
(0.0040)\end{array}$ & & $\begin{array}{c}0.0130 \\
(0.0147)\end{array}$ & & $\begin{array}{c}0.0199 \\
(0.0147)\end{array}$ & \\
\hline $\begin{array}{l}\text { Changes in predicted } \\
\text { tsunami height } \times \text { after } \\
\text { the } 2012 \text { revision }\end{array}$ & $\begin{array}{c}-0.0152 * * * \\
(0.0049)\end{array}$ & $\begin{array}{c}-0.0243 * * * \\
(0.0052)\end{array}$ & $\begin{array}{c}-0.0117 * * \\
(0.0059)\end{array}$ & $\begin{array}{c}-0.0127 * * * \\
(0.0040)\end{array}$ & $\begin{array}{c}0.0035 \\
(0.0048)\end{array}$ & $\begin{array}{l}0.0116 * * * \\
(0.0036)\end{array}$ \\
\hline $\begin{array}{l}\text { Predicted seismic } \\
\text { intensity ( } 1 \text { if upper } 6 \\
\text { or greater in } 2012 \text { but } \\
\text { lower } 6 \text { or less in } \\
\text { 2003) }\end{array}$ & $\begin{array}{c}0.0485 \\
(0.0494)\end{array}$ & & $\begin{array}{c}0.1829 \\
(0.1110)\end{array}$ & & $\begin{array}{c}0.1344 \\
(0.1016)\end{array}$ & \\
\hline $\begin{array}{l}\text { Predicted seismic } \\
\text { intensity } \times \text { after the } \\
2012 \text { revision }\end{array}$ & $\begin{array}{c}0.0048 \\
(0.0379)\end{array}$ & $\begin{array}{r}-0.0295 \\
(0.0506)\end{array}$ & $\begin{array}{r}-0.0322 \\
(0.0519)\end{array}$ & $\begin{array}{r}-0.0386 \\
(0.0372)\end{array}$ & $\begin{array}{r}-0.0370 \\
(0.0498)\end{array}$ & $\begin{array}{r}-0.0091 \\
(0.0377)\end{array}$ \\
\hline \multicolumn{7}{|l|}{ Fixed effects } \\
\hline Prefecture & Yes & No & Yes & No & Yes & No \\
\hline Municipality & No & Yes & No & Yes & No & Yes \\
\hline Year & Yes & No & Yes & No & Yes & No \\
\hline Prefecture $\times$ year & No & Yes & No & Yes & No & Yes \\
\hline Adjusted $R^{2}$ & 0.4321 & 0.5710 & 0.6926 & 0.9596 & 0.5888 & 0.9491 \\
\hline Sample size & 3072 & 3072 & 3072 & 3072 & 3072 & 3072 \\
\hline
\end{tabular}

$* * *, * *$, and $*$ indicate the estimated coefficients are significant at the 1,5 , and $10 \%$ levels, respectively. Robust standard errors clustered by municipality are presented in the parentheses. The following control variables are included in all estimations, but results are omitted from the table: the number of deaths/injuries from the 2011 earthquake and tsunami (per 10,000 residents), \% of population living in the 2011 tsunamiaffected areas, number of buildings damaged by the 2011 earthquake, municipalities covered by the Disaster Relief Act, distance from the Fukushima Nuclear Power Plant, predicted probability of an earthquake with JMA seismic intensity of upper 6 or greater, $\%$ of population aged $0-14, \%$ of population aged $65+$, population density, income per capita, the number of airports and railway stations, miles of public roads, the number of manufacturing establishments

Figure 5 compares the average net migration rates in treated municipalities with those of synthetic units. Figure 5a shows the results using a sample of all treated municipalities, whereas Fig. 5b-d show results using a subsample of treated municipalities with different levels of increase in tsunami predictions. In all cases, pre-treatment trends in net migration rate are nearly identical between the synthetic and treated municipalities. In comparison, post-treatment migration rates are lower in treated municipalities than in synthetic counterparts in all cases. Following Cavallo et al. (2013), we also conduct a placebo test for the average effects and find that the gap between actual and counterfactual migration rates are significant in most cases. These results are presented in Fig. 6.

Figure 5 also shows that the gap tends to be larger for municipalities with a greater increase in predicted tsunami height. Estimated effects are largest in 2013 and 
(a) Full Sample

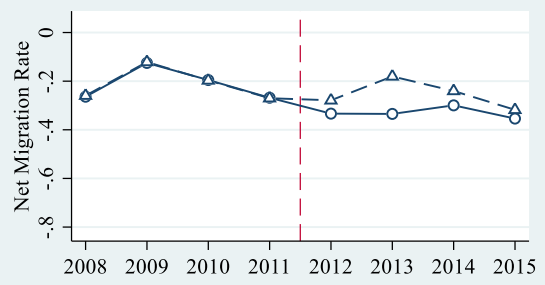

(c) $3-9 \mathrm{~m}$

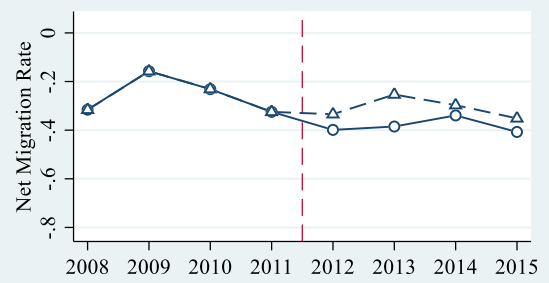

(b) $1-2 \mathrm{~m}$

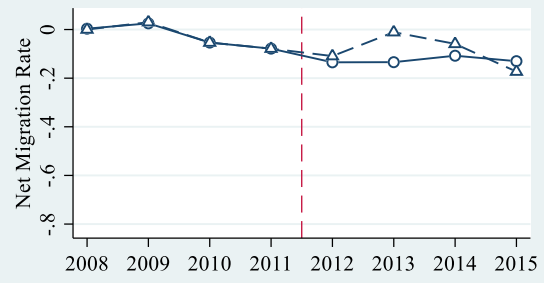

(d) $10 \mathrm{~m}+$

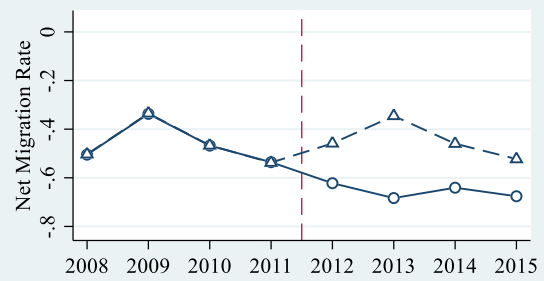

\section{$\longrightarrow$ Actual $--\Delta--$ Counterfactual}

Fig. 5 Actual and counterfactual migration rates

become smaller in later years. Although these estimates are not directly comparable to our regression results, the overall pattern is roughly consistent with our results presented in Table 4.

Overall, the results based on the SC method are consistent with our main empirical results. This suggests that our choice of control municipalities and the differential pre-treatment trends in migration rates do not pose a serious problem in our empirical analysis.

\section{Conclusion}

This paper examines the effect of the CDMC's 2012 revisions to earthquake and tsunami hazard information on subsequent inter-municipal migration patterns. We found that a rise in predicted tsunami height after the 2012 revisions is significantly associated with a reduction in net migration rate; this association has resulted from both a decline of in-migration and an increase in out-migration. Further analysis reveals that whereas the reducing effect of predicted tsunami height on in-migration persisted throughout the study period, the impact on out-migration was only temporary. Finally, the study finds that working-age people are more likely to respond to tsunami risk and avoid moving to municipalities with a high tsunami risk since the 2012 revisions. 
Our empirical analysis has important implications for the linkage between population dynamics and environmental hazards. Several previous studies point to the fact that population and environmental hazards are interrelated to each other (Hunter 2005; Donner and Rodríguez 2008). On the one hand, environmental hazards might influence population dynamics through migration and residential decision-making, whereby people move away or avoid moving into risky locations. On the other hand, migration into or out of a specific location would change the population size and composition, thereby influencing population exposure and vulnerability to natural disasters. Our empirical findings suggest that, while reduced migration into risky areas can decrease the overall population exposure to a tsunami hazard, heterogeneous migration responses across population subgroups might worsen the community's vulnerability conditions, resulting in the elderly population being left behind in risky areas.

Our results also have several important policy implications. First, we found significant migration responses to tsunami hazards but not to earthquake hazards. The rationale for this finding is that migration as an adaptation strategy to natural hazards depends not only on the severity of the event but also on the costs and benefits of other mitigation measures (Reuveny 2007). A great tsunami with a wave height above a certain level is so devastating that any mitigation measures (such as building coastal levees, seawalls, and tsunamiproof buildings) are either ineffective or too costly. Consequently, moving to a different place would be the only sensible option aimed at people facing an extremely serious tsunami hazard. On the other hand, quake-resistant buildings and a number of other less costly steps are available to cope with earthquake dangers. Thus, our findings suggest that policy options to reduce the risk of these two kinds of hazards should also be different. While encouraging relocation-and not allowing new development in-anticipated tsunami areas would be a good policy option to lower tsunami disaster risk, subsidizing seismic inspections and retrofitting costs, as well as enhancing community resilience to earthquakes, would be a good policy option to lessen earthquake risk.

Second, we find that an increased tsunami hazard is significantly associated with a reduction in the net migration rate. However, predictions of earthquake and tsunami hazards are not necessarily accurate due to the limitations of scientific knowledge. If the revised estimates are inadequate, people respond to the wrong information, and no risk reduction can be achieved. Furthermore, the long-lasting effects of revised tsunami height on in-migration indicate that there is a potential for continued stigmatization of municipalities with a massive tsunami risk, even years after the revisions. Better risk communication about the inherent uncertainty of hazard estimates, and periodic updating of existing estimates based on the best available scientific evidence, are necessary to avoid bias on people's risk reduction behaviors.

Third, we find that elderly people have continued to stay in municipalities with a high tsunami risk after the 2012 revision. Such information does not change their migration behavior because they may have personal ties to the region and often show a strong emotional connection to it. As a result, the proportion of elderly people in municipalities with a high tsunami risk is 
growing faster than in low-risk municipalities. Elderly people are known to be more vulnerable to tsunami hazards than the general population (Cutter et al. 2003; Donner and Rodríguez 2008). About 65\% of the deaths from the 2011 Great East Japan Earthquake and its related tsunami were concentrated among those aged 60 or older (Cabinet Office 2011). Policymakers need to pay special attention to prevention and evacuation plans in municipalities with a high proportion of elderly citizens.

The findings of this paper should be interpreted with caution. First, people might respond to a tsunami risk more than usual due to their prior exposure to news of the Great East Japan Earthquake and the subsequent tsunami. As a result, migration responses to the updated seismic and tsunami information can differ from what has been observed in other circumstances. However, since predicted tsunami height is significantly associated with changes in migration rates even within coastal areas or in areas without any direct damage from the 2011 tsunami, we believe that updated hazard information has some impact upon migration patterns in anticipated disaster areas (see our discussion in the "Robustness checks" section).

Second, people who move away from coastal municipalities might end up moving into neighboring inland areas. In this case, we may have double-counted the effect. Unfortunately, our data do not contain information on in-migrants' municipalities of origin or out-migrants' destinations. However, according to the census, $1.6 \%$ of out-migrants from coastal municipalities actually moved to neighboring inland areas between 2010 and 2015. This figure has not changed much from the figure from 2005 to 2010 , which is $1.7 \%$, suggesting that migration across neighboring areas has not seriously biased our estimates.

Third, this paper estimates the effect of the 2012 revisions of predicted seismic movements and the resulting tsunami height on "inter-municipality" migration. We do not take "intra-municipality" migration into account; rather, we leave this question to future research using census data from 2010 and 2015. Further research is necessary to identify effective prevention and evacuation plans and to improve disaster preparedness.

Acknowledgments We would like to thank Akiomi Kitagawa, Mamoru Maekawa, Tatsuyoshi Matsumae, Jun Nagayasu, Masayuki Nakagawa, Hayato Nakanishi, Shigeru Sugihara, Susumu Suzuki, Noriko Tamachi, Kingo Toyoda, Takayuki Tsuruga, Hiroshi Tubouchi, and Midori Wakabayashi, as well as seminar participants in the Economic and Social Research Institute, Tohoku University, the 31st annual meeting of the Applied Regional Science Conference (University of Tokyo) and the 2017 International Conference on Sustainable Development (Columbia University). We would also like to thank the editor and three anonymous reviewers for their helpful comments. Part of this work was conducted while the first author was a visiting scholar at the University of Southern California.

Funding information This study was supported by the Japan Society for the Promotion of Science (JSPS) KAKENHI, Grant No. JP17H02072 (PI: Shingo Nagamatsu) and the Ministry of Education, Culture, Sports, Science and Technology (MEXT)-Supported Program for the Strategic Research Foundation at Private Universities, Grant No. S1491002 (Naoi). 


\section{Appendix 1. Description and source of control variables}

Table 9 Description and source of control variables

\begin{tabular}{l} 
Variables \\
\hline $\begin{array}{l}\text { Number of deaths/injuries } \\
\text { from the } 2011 \text { earth- } \\
\text { quake (per } 10,000 \text { resi- } \\
\text { dents) }\end{array}$ \\
$\%$ of residents living in the \\
2011 tsunami-affected \\
areas \\
Number of buildings \\
damaged by the 2011 \\
earthquake (per 10,000 \\
residents)
\end{tabular}

Description

Source
Municipalities covered by the Disaster Relief Act

Distance from the Fukushima Nuclear Power Plant (km)

Probability of an earthquake with JMA seismic intensity of upper 6 or greater 2011 earthquake divided by the total population of each municipality

Number of residents living in the 2011 tsunami areas divided by the total population of each municipality

Number of buildings collapsed during or partially damaged by the 2011 earthquake divided by the total population of each municipality

Dummy variable taking the value of one if the municipality is covered by the Disaster Relief Act

Distance from the Fukushima Daiichi Nuclear Power Plant

Probability that an earthquake with JMA seismic intensity of upper 6 or greater will occur within the next 30 years

$\%$ of population aged $0-14$ Population aged $0-14$ and $65+$ divided and $65+$

Population density (per sq. $\mathrm{km}$ ) by the total population of each municipality

Total population divided by land area of the municipality

Per capita income $(10,000$ yen)

Number of airports (per sq $\mathrm{km}$ )

Number of railway stations
Total taxable income for resident tax divided by the total population of each municipality

Number of major airports divided by the land area of the municipality
Number of deaths and injuries from the

Number of deaths/injuries: White Paper on Fire and Disaster Management (Fire and Disaster Management Agency)

Municipal population: Report on Internal Migration (Statistics Bureau)

Tsunami-affected areas: Report on 2011 Tsunami Exposure (Geospatial Information Authority of Japan)

\section{Number of buildings} collapsed/damaged: White Paper on Fire and Disaster Management (Fire and Disaster Management Agency)

Disaster Relief Act: Report on the Application of the Disaster Relief Act (Ministry of Health, Labour, and Welfare)

Fukushima Daiichi Nuclear Power Plant: National Land Numerical Information (Ministry of Land, Infrastructure, Transport and Tourism)

Probability of an earthquake: Probabilistic Seismic Hazard Map (National Research Institute for Earth Science and Disaster Prevention)

Age-specific population: Report on Internal Migration (Statistics Bureau)

Land area: Report on Land Area of Prefectures and Municipalities (Geospatial Information Authority of Japan)

Taxable income: Report on Municipal Taxes (Ministry of Internal Affairs and Communications)

Airports: National Land Numerical Information (Ministry of Land, Infrastructure, Transport and Tourism)

Railway stations: National Land Numerical Information (Ministry of Land, Infrastructure, Transport and Tourism) 
Table 9 (continued)

\begin{tabular}{lcc}
\hline Variables & Description & Source \\
\hline $\begin{array}{l}\text { Length of public roads (per } \\
\text { sq. km) }\end{array}$ & $\begin{array}{c}\text { Public road length (national, } \\
\text { prefectural, and municipal) divided } \\
\text { by land area of the municipality }\end{array}$ & $\begin{array}{c}\text { Pubic road length: Report on Current } \\
\text { Status of Road Infrastructure } \\
\text { (Ministry of Land, Infrastructure, } \\
\text { Transport and Tourism) }\end{array}$ \\
$\begin{array}{l}\text { Number of manufacturing } \\
\text { establishments (per sq. } \\
\text { km) }\end{array}$ & $\begin{array}{c}\text { Number of manufacturing } \\
\text { establishments divided by land area } \\
\text { of the municipality }\end{array}$ & $\begin{array}{c}\text { Manufacturing establishments: Census } \\
\text { of Manufacture (Ministry of } \\
\text { Economy, Trade and Industry) }\end{array}$ \\
\hline
\end{tabular}

Data on the number of airports and railway stations, length of public roads, and number of manufacturing establishments are not available for some years during our sample period. The missing values are linearly interpolated using values in adjacent years in order to have a balanced panel

\section{Appendix 2 The synthetic control method}

While the original setup in Abadie et al. (2010) considers a situation with a single treated unit, there are several recent papers that extend the original setup to cases with multiple treated units (Acemoglu et al. 2016; Cavallo et al. 2013). We follow Cavallo et al. (2013)'s procedure to estimate the average effects

We first outline a standard SC framework for a given treated municipality. This allows us to estimate the effect of 2012 revisions on migration patterns for each treated municipality. These municipality-specific effects are then aggregated over treated municipalities to obtain an average effect

Suppose we observe $J+1$ municipalities over $t=1, \cdots, T$. Treatment, revised tsunami predictions, is given in $t=T_{0}$. Municipalities are indexed by $i=1, \cdots, J+1$, with municipality one $(i=1)$ being treated (i.e., receive an increased tsunami prediction in $\left.t=T_{0}\right)$ and the remaining municipalities $(i=2, \cdots, J+1)$ being control municipalities ${ }^{1}$

Let $y_{i, t}$ be an observed outcome, the migration rate for municipality $i$ at time $t$, and $y_{i, t}^{N}$ be a "counterfactual" outcome that would be observed in the absence of any updated information. We assume that updated information only affects the treated municipality for $t \geq T_{0}$. We also assume that updated information does not affect outcomes before its release, so that $y_{i, t}=y_{i, t}^{N}$ for all $i$ and $t<T_{0}$

We aim to identify the impact of updated hazard information on the treated municipality, $\tau_{1, t}$. For $t \geq T_{0}$, these are given by

$$
\tau_{1, t}=y_{1, t}-y_{1, t}^{N}
$$

Note that $y_{1, t}$ is observed. Therefore, to estimate $\tau_{1, t}$, we only need to construct the unobserved counterfactual $y_{1, t}^{N}$

\footnotetext{
${ }^{1}$ In the following analysis, we restrict a set of control municipalities to that used in our main empirical analysis. That is, inland municipalities adjacent to treated municipalities.
} 
The basic idea of the SC method is to construct a "synthetic" unit as an appropriate combination of control municipalities to estimate the counterfactual outcome $y_{1, t}^{N}$. A synthetic unit is constructed in a way that its pre-treatment outcomes $y_{i, t}$ and relevant characteristics $z_{i}$ are approximately matched with those of the treated municipality. This means that there exist some weights $\left(w_{2}^{*}, \cdots, w_{J+1}^{*}\right)$ with $w_{j}^{*} \geq 1$ and $\sum_{j=2}^{J+1} w_{j}^{*}=1$ such that

$$
\begin{gathered}
\sum_{j=2}^{J+1} w_{j}^{*} y_{j, t}=y_{1, t} \quad \forall t \in\left\{1, \cdots, T_{0}-1\right\} \\
\sum_{j=2}^{J+1} w_{j}^{*} z_{j}=z_{1}
\end{gathered}
$$

where $z_{j}$ is a vector of covariates not affected by the treatment. ${ }^{2}$ Abadie et al. (2010) suggest using

$$
\widehat{\tau}_{1, t}=y_{1, t}-\sum_{j=2}^{J+1} w_{j}^{*} y_{j, t} \quad \forall t \in\left\{T_{0}, \cdots, T\right\}
$$

as an estimator of $\tau_{1, t}{ }^{3}$

Cavallo et al. (2013) extend the method to incorporate multiple treated units. The idea is to estimate a separate $\tau_{i}$ vector for each treated unit based on the original SC setup and then aggregate these municipality-specific effects to obtain an average effect:

$$
\bar{\tau}=\left\{\bar{\tau}_{T_{0}}, \cdots, \bar{\tau}_{T}\right\}=\frac{1}{N_{T}} \sum_{i=1}^{N_{T}}\left\{\widehat{\tau}_{i, T_{0}}, \cdots, \widehat{\tau}_{i, T}\right\}
$$

where $N_{T}$ is a number of treated units and $\widehat{\tau}_{i, t}$ is the municipality-specific effect for treated municipality $i$ obtained by Eqs. (A2)-(A4)

Since conventional large sample inference is not readily available for the SC method, we employ a permutation method proposed by Cavallo et al. (2013). The method is outlined as follows. In the first step, we estimate a "placebo" treatment effect for each municipality in the control group. That is, we pick a single municipality from the control group as a placebo treatment unit and estimate a placebo treatment effect based on the SC method outlined above (using the remaining municipalities as control units). This leads to the placebo dynamics for each $j$ in control group:

$$
\widehat{\tau}_{j}^{p}=\left\{\widehat{\tau}_{j, T_{0}}^{p}, \cdots, \widehat{\tau}_{j, T}^{p}\right\}
$$

In the second step, we compute average placebo effects for a possible combination of placebo units. Specifically, we randomly draw a set of placebo units of size $N_{T}$ from control municipalities and compute average effects as in Eq. (A5). We repeat this

\footnotetext{
${ }^{2}$ In the following analysis, $z_{j}$ includes pre-treatment averages of the municipality characteristics that are also used in our main empirical analysis.

${ }^{3}$ The actual estimation is done by using Stata's synth package.
} 
procedure for $N_{R}$ times to construct the empirical distribution of average placebo effects $^{4}$

Let $\bar{\tau}^{p(l)}=\left\{\bar{\tau}_{T_{0}}^{p(l)}, \cdots, \bar{\tau}_{T}^{p(l)}\right\}$ be the computed average placebo effect for the $l$ th draw. The $p$ value for the average treatment effect at time $t$ is then computed as

$$
p_{t}=\frac{\sum_{l=1}^{N_{R}} I\left(\left|\overline{\bar{\tau}}_{t}^{p(l)}\right| \geq\left|\bar{\tau}_{t}\right|\right)}{N_{R}}
$$

for $t=T_{0}, \cdots, T$

Figure 6 presents the estimated average effects and their associated $p$ values. The results indicate that a reduction in net migration rate is larger in municipalities that experienced a greater increase in predicted tsunami height. Throughout the posttreatment period, the estimated effects on the net migration rate are statistically significant at least at the $10 \%$ level for municipalities with a more than $3 \mathrm{~m}$ increase in predicted tsunami height.
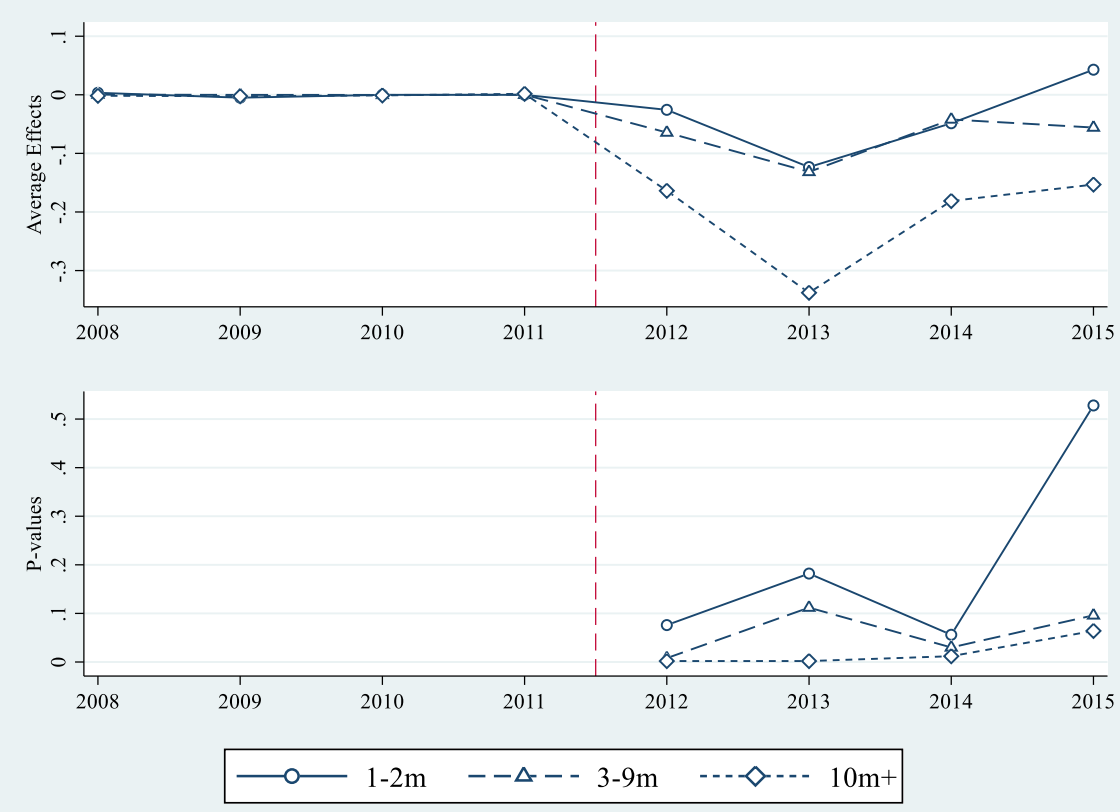

Fig. 6 Average effects of changes in predicted tsunami height

${ }^{4}$ Ideally, this can be done for every possible combination of placebo units of size $N_{T}$. However, given our size of treatment units $\left(N_{T}=235\right)$ and control (placebo) units $\left(N_{C}=\right.$ 195 ), this is infeasible. We therefore set $N_{R}=500$ in our empirical analysis. 
Open Access This article is licensed under a Creative Commons Attribution 4.0 International License, which permits use, sharing, adaptation, distribution and reproduction in any medium or format, as long as you give appropriate credit to the original author(s) and the source, provide a link to the Creative Commons licence, and indicate if changes were made. The images or other third party material in this article are included in the article's Creative Commons licence, unless indicated otherwise in a credit line to the material. If material is not included in the article's Creative Commons licence and your intended use is not permitted by statutory regulation or exceeds the permitted use, you will need to obtain permission directly from the copyright holder. To view a copy of this licence, visit http://creativecommons.org/licenses/by/4.0/.

\section{References}

Abadie, A., Diamond, A., \& Hainmueller, J. (2010). Synthetic control methods for comparative case studies: Estimating the effect of California's tobacco control program. Journal of the American Statistical Association, 105, 493-505. https://doi.org/10.1198/jasa.2009.ap08746.

Acemoglu, D., Johnson, S., Kermani, A., Kwak, J., \& Mitton, T. (2016). The value of connections in turbulent times: Evidence from the United States. Journal of Financial Economics, 121, 368-391. https://doi. org/10.1016/j.jfineco.2015.10.001.

Ando, M. (1975). Source mechanisms and tectonic significance of historical earthquakes along the Nankai trough, Japan. Tectonophysics, 27, 119-140. https://doi.org/10.1016/0040-1951(75)90102-x.

Bardsley, D. K., \& Hugo, G. J. (2010). Migration and climate change: Examining thresholds of change to guide effective adaptation decision-making. Population and Environment, 32, 238-262. https://oi. org/10.1007/s11111-010-0126-9.

Bohra-Mishra, P., Oppenheimer, M., Cai, R., Feng, S., \& Licker, R. (2017). Climate variability and migration in the Philippines. Population and Environment, 38, 286-308. https://doi.org/10.1007/s11111-016-0263$\mathrm{x}$.

Boustan, L. P., Kahn, M. E., \& Rhode, P. W. (2012). Moving to higher ground: Migration response to natural disasters in the early twentieth century. The American Economic Review, 102, 238-244. https://doi. org/10.1257/aer.102.3.238.

Brookshire, D. S., Thayer, M. A., Tschirhart, J., \& Schulze, W. D. (1985). A test of the expected utility model: Evidence from earthquake risks. Journal of Political Economy, 93, 369-389. https://doi.org/10.1086 /261304.

Cabinet Office. (2011). White paper on disaster prevention 2011 (Bosai Hakusho). Ministry of Finance: Printing Bureau.

Cavallo, E., Galiani, S., Noy, I., \& Pantano, J. (2013). Catastrophic natural disasters and economic growth. Review of Economics and Statistics, 95(5), 1549-1561. https://doi.org/10.1162/REST_a_00413.

Cutter, S. L., Boruff, B. J., \& Shirley, W. L. (2003). Social vulnerability to environmental hazards. Social Science Quarterly, 84, 242-261. https://doi.org/10.1111/1540-6237.8402002.

Dallmann, I., \& Millock, K. (2017). Climate variability and inter-state migration in India. CESifo Economic Studies, 63, 560-594. https://doi.org/10.1093/cesifo/ifx014.

Deryugina, T. (2017). The fiscal cost of hurricanes: Disaster aid versus social insurance. American Economic Journal: Economic Policy, 9, 168-198. https://doi.org/10.1257/pol.20140296.

Dillon, A., Mueller, V., \& Salau, S. (2011). Migratory responses to agricultural risk in northern Nigeria. American Journal of Agricultural Economics, 93, 1048-1061. https://doi.org/10.1093/ajae/aar033.

Donner, W., \& Rodríguez, H. (2008). Population composition, migration and inequality: The influence of demographic changes on disaster risk and vulnerability. Social Forces, 87, 1089-1114.

Furumura, T., Imai, K., \& Maeda, T. (2011). A revised tsunami source model for the 1707 Hoei earthquake and simulation of tsunami inundation of Ryujin Lake, Kyushu, Japan. Journal of Geophysical Research, 116, 1-17. https://doi.org/10.1029/2010jb007918.

Gray, C. L., and Mueller, V. (2012). Natural disasters and population mobility in Bangladesh. Proceedings of the National Academy of Sciences, 109, 6000-6005. doi: https://doi.org/10.1073/pnas.1115944109.

Hunter, L. M. (2005). Migration and environmental hazards. Population and Environment, 26, $273-302$. https://doi.org/10.1007/s11111-005-3343-x.

Hunter, L. M., Luna, J. K., \& Norton, R. M. (2015). Environmental dimensions of migration. Annual Review of Sociology, 41, 377-397. https://doi.org/10.1146/annurev-soc-073014-112223. 
Husby, T. G., de Groot, H. L. F., Hofkes, M. W., \& Dröes, M. I. (2014). Do floods have permanent effects? Evidence from the Netherlands. Journal of Regional Science, 54, 355-377. https://doi.org/10.1111 /jors. 12112.

Ishibashi, K. (2004). Status of historical seismology in Japan. Annales de Geophysique, 47, 339-368. https://doi.org/10.4401/ag-3305.

Loebach, P. (2016). Household migration as a livelihood adaptation in response to a natural disaster: Nicaragua and Hurricane Mitch. Population and Environment, 38, 185-206. https://doi.org/10.1007 /s11111-016-0256-9.

Matsuura, H., \& Sato, K. (2018). Economic evaluation of multi-hazard risk information in Japan: Implication for earthquake risk communication. In C. V. Fletcher \& J. Lovejoy (Eds.), Natural disasters and risk communication: Implications of the Cascadia subduction zone megaquake. Lexington, MA: Lexington Press.

Millock, K. (2015). Migration and environment. Annual Review of Resource Economics, 7, 35-60. https://doi. org/10.1146/annurev-resource-100814-125031.

Myers, C. A., Slack, T., \& Singelmann, J. (2008). Social vulnerability and migration in the wake of disaster: The case of Hurricanes Katrina and Rita. Population and Environment, 29, 271-291. https://doi. org/10.1007/s11111-008-0072-y.

Nakanishi, H. (2016). How the change of risk announcement on catastrophic disaster affects property prices. In G. Chichilnisky \& A. Rezai (Eds.), The economics of the global environment-Catastrophic risks in theory and policy (pp. 577-595). New York: Springer.

National Research Institute for Earth Science and Disaster Resilience (2016) Probabilistic Seismic Hazard Map 2008-2016 (accessed October 25, 2016). doi: https://doi.org/10.17598/nied.0010.

Reuveny, R. (2007). Climate change-induced migration and violent conflict. Political Geography, 26, 656673. https://doi.org/10.1016/j.polgeo.2007.05.001.

Schultz, J., \& Elliott, J. R. (2013). Natural disasters and local demographic change in the United States. Population and Environment, 34, 293-312. https://doi.org/10.1007/s11111-012-0171-7.

Singh, R. (2019). Seismic risk and house prices: Evidence from earthquake fault zoning. Regional Science and Urban Economics, 75, 187-209. https://doi.org/10.1016/j.regsciurbeco.2019.02.001.

Xu, H., \& Wang, S. (2019). Urban redevelopment and residential location choice: Evidence from a major earthquake in Japan. Journal of Regional Science. https://doi.org/10.1111/jors.12424.

Publisher's note Springer Nature remains neutral with regard to jurisdictional claims in published maps and institutional affiliations.

\section{Affiliations}

\section{Michio Naoi ${ }^{1} \cdot$ Keiichi Sato ${ }^{2} \cdot$ Yozo Tanaka $^{3} \cdot$ Hiroaki Matsuura $^{4} \cdot$ Shingo Nagamatsu $^{5}$}

1 Faculty of Economics, Keio University, 2-15-45 Mita, Minato-ku, Tokyo 108-8345, Japan

2 Senshu University, Kanagawa, Japan

3 Collage of Land, Infrastructure, Transport and Tourism, Tokyo, Japan

4 Shoin University, Kanagawa, Japan

5 Kansai University, Osaka, Japan, and the National Research Institute for Earth Science and Disaster Resilience, Ibaraki, Japan 